\title{
REFLECTIONS ON THE PROVINCIALISM OF POLISH POLITICAL SCIENCE
}

\section{TOMASZ WARCZOK, TOMASZ ZARYCKI, GRA PERYFERYJNA. POLSKA POLITOLOGIA W GLOBALNYM POLU NAUK SPOŁECZNYCH}

Jarosław Kilias

University of Warsaw

In the fall of 2016 Scholar published a book entitled Gra Peryferyjna. Polska politologia w globalnym polu nank spokecznych [A Peripheral Game: Polish Political Science in the Global Social Science Field] by Tomasz Warczok and Tomasz Zarycki. The book is a sequel to a series of works in which the authors employ the concept of the centre-periphery divide to explain Poland's pattern of development. Some of the works have already dealt with the country's social science (e.g., Warczok \& Zarycki 2014; Warczok 2016), but Gra Peryferyjna is the first monograph on a particular academic discipline: political science.

The book opens with a comprehensive presentation of a variety of sociological theories of science and/or knowledge. Starting from the ideas of Émile Durkheim, the authors review the concepts and ideas of such thinkers as Karl Marx, Karl Mannheim, and especially Robert K. Merton. As for more up-to-date ideas on the sociology of scientific knowledge, only Barry Barnes's and David Bloor's "strong programme" is presented. Two theories are described in a more detailed way: Pierre Bourdieu's analyses of science and academic fields and Randall Collins's theory of interaction rituals. Most of the concepts presented in the introduction do not relate to the topic of the book, the centre-periphery divide, or to dependent development in any direct way. Curiously, the 
chapter deals mostly with Bourdieu's analysis of science, and not his study of the academic field (Bourdieu 1988), which would have been much more relevant to the analysis of international political science. Furthermore, the authors not only ignore current science and technology studies, they also overlook the existing literature on academic dependency (e.g., Alatas 2003; Sinha-Kerkhoff \& Alatas 2010), which should have formed the theoretical backbone of their argument.

The second chapter deals with a number of different subjects. It introduces another of Warczok and Zarycki's theoretical inspirations, that is, Immanuel Wallerstein's theory of world systems, with its distinction between the core, the peripheries, and the semi-peripheries of the system. Later in the same chapter they describe Poland's position as a periphery of the capitalist West. One may of course wonder how the country's position has been influenced by belonging to the communist zone and by the changing geopolitical situation, but there is no answer to such questions in the book. In fact, the authors do not offer any actual analyses of Poland's history or its economy, simply asserting that the country has always been a periphery of the Western world. Instead, they describe the role of the intelligentsia as a specific stratum that has been living on a supposedly close relation with the core, and the dualism of peripheral knowledge production, which is usually divided between institutions connected to foreign centres and ones that participate solely in the local circulation of ideas.

In the third chapter the authors explore the structure of the global social science field. Having analysed the original language of translations published in various countries, Warczok and Zarycki suggest that the dominant, American section of the Western core provides most of the quantitative research, while most new and original ideas come from Europe, and especially France. They also describe the development of the institutional infrastructure of political science, including the histories of the International Political Science Association and the European Consortium for Political Research. In chapters four and five the authors deal with the history of political science in Eastern and Central Eastern Europe, including in Poland. They show how local political science emerged mostly from faculties of law and relatively late compared to other social sciences, achieving institutional autonomy only in the late 1960s. In Poland, political science retained a close connection with communist politics for a long time, and the political science discipline often served as a means of social advancement for party bureaucrats. 
The disciplinary status of the new branch remained ambiguous and its academic prestige was lower than that of other social sciences, especially sociology. It probably attracted more students from provincial regions, with lower social capital, than did its more prominent academic counterpart. Its closeness to the power elite and the dominance of official Marxism caused a serious crisis after 1989, when political science became a subject of criticism and underwent a partial reconstruction, which resulted in the formation of a number of new institutions that were not heirs of any socialist predecessors.

The final chapters of the book deal with the international status of Polish political science, as measured mostly by citations indexed by the Web of Science. Applying their concept of the institutional duality of peripheral science, the authors show that the duality is relatively insignificant in Poland and takes the most rudimentary form in sources of local and international academic capital. Interestingly, most Westernoriented scholars (who also participate in international academic life) are people from the intellectual margins of the branch, especially political sociologists and social psychologists.

To assess Warczok and Zarycki's book is by no means an easy task. The authors have set themselves the overly ambitious aim of analysing the place of Polish political science in global social science. They declare that they are going to apply Immanuel Wallerstein's theory of world systems and not merely use the words "system," "core," or "periphery." Surprisingly, as another theoretical instrument, Warczok and Zarycki selected Pierre Bourdieu's theory of fields. One may of course wonder how Bourdieu's ideas can at all combine with Wallerstein's. Unfortunately, there is no trace of an answer to this question in the book, and the authors make liberal use of such words as the "core," "periphery," or "semi-periphery." It is not clear whether they realise the fundamental difference between the latter two concepts (at least from Wallerstein's perspective) as they avail themselves of both in dealing with Polish political science (e.g., Warczok \& Zarycki 2016: 43, 45, 247). They never attempt to use this theory to examine the actual mechanisms of academic dependency (compare Alatas 2003). Although Warczok and Zarycki employ the term "semi-periphery" at times, they do not disclose any semi-peripheral development strategies based on a specific position between the centre and more distant academic peripheries. Obviously, Wallerstein's theory serves them only as a source of vague metaphors. In general, theory is not one of the book's assets. Among the many theories 
described in the opening chapters, only Bourdieu's seems to be actually applied and the rest function merely as ornament to give the book a more academic and less essayistic look. Even the case of Bourdieu is slightly problematical. The original Bourdieusian (1988) analysis of the academic field included considerable data on its socio-political context and the social background and biographies of individual scholars; it offered a truly synthetic view of French academia amidst the class and power hierarchies of French society. Warczok and Zarycki almost conflate the field of international political science (...but is it really a field in the Bourdieusian sense?) with intellectual production, and especially with papers and citations (as indexed by the Web of Science). Unfortunately, Web of Science is hardly an effective instrument to deal with a peripheral social science in the context of historical change, as it offers a limited capacity for cross-time comparison and is an instrument of the academic dominance of the core itself. On the other hand, one may ask how it is possible to describe an academic discipline without analysing a single scholarly work, as the authors of Gra peryferyjna do in the case of Polish political science. They do not take into account any data on the political or economic power relations within international academia, which are the key factors shaping international social science. Clearly, analyses by students of academic dependency, such as Syed Farid Alatas, would have been a much more useful inspiration than the works of Collins or the antiquated ideas of Merton.

Measured only by the declared research goals or the theoretical ambitions of the authors, Gra peryferyjna is a pioneering work in the sociology of social science, but also an evident failure. Although it offers a wide range of data on the social and institutional history and the functioning of political science in Poland and abroad, it lacks the requisite data, the effective application of theoretical instruments, and the analytical rigour to deal with academic dependency.

Fortunately, the book could be read in at least two other ways. First, Gra peryferyjna can be considered as a slightly one-sided but comprehensive, relatively rich in detail, and well-written social and institutional history of Polish and international political science. Second, despite the type and range of empirical evidence used in the book, it can be read not as an analytical, theory-laden study, but as an essay on the provincialism - or, in the usual, non-academic sense of the word, peripherality - of Polish political science. For a historian, the most interesting parts are the authors' observations regarding the social role of political science 
in the communist countries as a vehicle for the social advancement of Party cadres, and political science's relation to sociology, especially the differences between the cultural capital of the academic cadres of the two branches. Would that they had been studied in more detail and supported by more empirical data! As an essay on the peripherality of Polish political science the book offers a few thought-provoking observations and ideas and a lot of interesting information, especially on international scholarly production. Probably the most important and original item is the concept of the institutional duality of peripheral science. Paradoxically, the phenomenon of institutional duality plays a rather marginal role in Polish political science, being much more visible in places that are more peripheral to the Western academic core. Once again, similar observations by established students of academic dependency, especially Alatas, might have helped the authors to refine their idea and turn it into a genuine theoretical concept. It would have enabled them not to invent their theoretical and analytical instruments from scratch and might have allowed them to compare the case of Polish political science with the forms and types of academic dependency in countries of the global south. On the other hand, among the book's obvious strengths are the reflections on the socio-psychological effects of peripherality and its impact on local (mundane) academic discourse and strategies of academic capital-building.

All in all, Gra peryferyjna is a thought-provoking work which offers the reader a lot of interesting information on Polish and international social science, together with a few useful concepts and reflections on academic dependency. Still, the book requires a critical reader, who does not take all the authors' proclamations and assertions at face value.

Bibliography:

/// Alatas S.F. 2003. "Academic Dependency and the Global Division of Labour in the Social Sciences," Current Sociology, vol. 51(6), pp. 599-613.

/// Bourdieu P. 1988. Homo Academicus, Stanford University Press.

/// Sinha-Kerkhoff K.R., Alatas S.F., eds. 2010. Academic Dependency in the Social Sciences: Structural Reality and Intellectual Challenges, Manohar. 
/// Warczok T. 2016. "Globalne pole nauk społecznych a socjologia polska. Zarys centro-peryferyjnego przepływu idei," [in:] Polska jako peryferie, ed. T. Zarycki, Scholar, pp. 170-186.

/// Warczok T., Zarycki T. 2014. “(Ukryte) zaangażowanie i (pozorna) neutralność: Strukturalne ograniczenia rozwoju socjologii krytycznej w warunkach półperyferyjnych,” Stan Rzeczy, vol. 6(1), pp. 129-158.

/// Warczok T., Zarycki T. 2016. Gra peryferyjna. Polska politologia w globalnym polu nauk spotecznych, Scholar.

/// Jarosław Kilias - Ph.D. (1965), works at the Institute of Sociology, University of Warsaw. His main fields of interests are the history of Polish and Czech sociology, and historical sociology. His publications include, among other works, the monographs Wspólnota abstrakcyjna. Zarys socjologii narodu [Abstract Community: An Outline of a Sociology of the Nation] (2004) and Jak socjologowie opowiadali o socjologii [How Sociologists Have Narrated Sociology] (2012). Recently he published the book Goście ze Wschodu. Socjologia polska lat sześćdziesiatych a nauka światowa [Visitors from the East: Polish Sociology of the 1960s and International Social Science] (2017).

Email: kilias@o2.pl 